\title{
Short Communication: A Comparative Analysis of Municipal Urban Tree Inventories of Selected Major Cities in North America and Europe
}

\author{
Julie Kjeldsen-Kragh Keller and Cecil C. Konijnendijk
}

\begin{abstract}
Eeffective management of the urban forest calls for municipalities to have a tree inventory of their urban resource. The approach to urban forestry is rather different in Europe and North America, both in terms of background and culture. This contribution discusses similarities and differences in tree inventory practices, based on a pilot study of three major cities in North America (Toronto, Ontario, Canada; and Boston, Massachusetts and New York City, New York, U.S.) and three major cities in Northern Europe (Oslo, Norway; and Aarhus and Copenhagen, Denmark). The pilot study consisted of semi-structured expert interviews in each city, and an analysis of their tree inventories in terms of their level of detail, how they were undertaken, and how they have been used. Each of the cities, with exception of Oslo, had inventoried all of their street trees. Volunteers were only used in Boston and New York City. None of the cities had developed a management plan based on their tree inventory. The inventory had only been completely incorporated into the work order system in New York City and Toronto. This explorative study shows that more research is needed to investigate what subsequently happens to tree inventories in municipalities after they have been performed. Moreover, more work is needed to identify whether inventories are being utilized to their full advantage in terms of producing management plans. Some key themes for further research are described. The set up of this pilot study could serve as a format for comprehensive research.

Key Words. Tree Vitality Assessment; Urban Forest Management; Urban Forest Resource Assessment; Urban Forestry; Volunteers.
\end{abstract}

The urban forest can be described as encompassing all of the woody and associated vegetation in a city, including street trees, residential trees, park trees, and woodland and greenbelt vegetation (Miller 1997; Sudha and Ravindranath 2000). In order to manage an urban forest it is vital to know and understand the resource. It is the structure of the urban forest that provides the basis for its functions (McPherson et al. 1997), and subsequently its value as a resource. It has been stressed that inventories are an important component in the management of urban forests (Smiley and Baker 1988; Miller 1997; Duntemann and Gasperini 2006; Jim 2008), and an urban tree inventory would therefore be the first step in planning and managing the urban forest for prioritized functions and values (Miller 1997; Cumming et al. 2008; Jim 2008).

The concept and cultural background (Vollbrecht 1988) of urban forestry differs between North America and Europe, and urban forestry seems to be more institutionalized in North America (Konijnendijk et al. 2006). Therefore the approach to tree inventories may also differ between the two continents.

The current literature on urban tree inventories often focuses on inventory results, in terms of environmental impact, tree health, and monetary benefits (McPherson et al. 1997; Gartner et al. 2002), and the species and composition ( $\mathrm{Jim} 2008$ ) of the urban forest. Other studies focus on how to perform the inventory, for example, with the use of geospatial methods (Ward and Johnson 2007), the use of Urban Forest Effects Model (UFORE), currently i-TREE Eco (McPherson et al. 1997), or the STRATUM inventory, currently i-Tree Streets (Millward and Sabir 2011; Soares et al. 2011).

A review of existing literature reveals a wide variety of reasons for performing a tree inventory. This ranges from traffic safety; a renewal of the urban forest (Petersen 2003); an increased number of tree failures (Duntemann and Gasperini 2006); assisting in the planning, identification and prioritization of arboricultural work (Smiley and Baker 1988; Petersen 2003; Jim 2008), evaluating the costs involved in managing the urban forest (Banks et al. 1999); and predicting arboricultural work required in the future (Banks et al. 1999; Brack 2006).

One relevant concern regarding inventories is the focus on public trees (Miller 1997; Banks et al. 1999; Brack 2006; Nowak 2008), and most inventories conducted by municipalities contain only street trees (Ward and Johnson 2007). These inventories will not be as comprehensive as an inventory that includes the entire urban forest (Nowak 2008), especially since the distribution and composition of private trees (Stewart 2009) and public parks (Welch 1994) is likely to be different than of populations of street trees.

The use of volunteers can be an important component of tree inventorying by ameliorating the limited resources available to municipal authorities. Studies have shown numerous benefits from this, such as increased survival of newly planted trees, sense of social identity among residents (Ames 1980), and empower- 
ment of citizens to take better care of their community and local environment (Bloniarz and Ryan 1996). However, using volunteers might bring up concerns over the validity of the results.

\begin{abstract}
AIMS
The aim of the presented pilot study was to test a frame for analyzing the state and use of urban tree inventories in major cities, to obtain insight into the status of inventories in major cities, as well as to identify directions for future, more comprehensive research on inventories. The study aimed to gain an indicative insight into the reasons for undertaking municipal tree inventories and a better understanding of how these inventories are performed. Moreover, the study authors wanted to analyze the differences in how cities' approach their inventories, and study what comes of the inventories after they have been performed. In addition, the study authors wanted to investigate whether a potentially different approach to urban forestry in the two continents are affecting how inventories are being performed, updated, and used.
\end{abstract}

\section{METHODS}

A pilot study was carried out in selected cities in North America (Toronto, Ontario, Canada; and Boston, Massachusetts and New York City, New York, U.S.) and Northern Europe (Oslo, Norway; and Aarhus and Copenhagen, Denmark). Semi-structured expert interviews were performed with the city's urban foresters in Toronto, New York City, Aarhus, Copenhagen, and Oslo. The authors contacted each city's urban forestry departments, and was put in further contact with the most appropriate urban forester for the interviews. Due to time restrictions, it was not possible to interview city officials in Boston, and interviews were instead performed with the non-profit group that had undertaken the inventory in collaboration with the city.

The six cities were chosen based on them being major cities in their region, the knowledge that they had already performed tree inventories, and the authors' understanding that these cities have inspired the development of urban forestry programs in other cities. Scandinavian cities were chosen because of the authors' own location and experience. The study authors had an additional interest in comparing regional cities with their counterparts in North America, where urban forestry has had a longer history and where arborists seem to have been playing a more pronounced role in greenspace management than in Europe (Konijnendijk et al. 2006). For example, there are only 42 ISA Certified Arborists in all of Denmark (Sejr and Manning 2011) and 33 in Norway, numbers which are surpassed by those in the single cities of Toronto (80) and New York City (41) (International Society of
Arboriculture 2011). Vollbrecht (1988) also pointed at this difference, stressing that most of the regional tree work was carried out by workers with a horticultural background. A study into how tree inventories are performed will give more insight into the potential differences in how urban forestry is performed in the two regions.

All of the interviews were carried out face-to-face by one of the study authors in the period from March to June 2010. If further information was required, follow up questions were asked via e-mail. The questions asked to the urban foresters are presented in Table 1. Descriptive tables were created to compile and compare findings, including the types of information each inventory collected, who performed the inventory, and how the inventory has been used.

\section{RESULTS}

The tree inventories differed greatly between the six cities in their level of detail and the means by which they are being updated and kept relevant, if they are being maintained at all. General information regarding the cities in the pilot study and their given reasons for undertaking the inventory is presented in the appendix. Table 2 illustrates what information was collected in each inventory, who performed the inventories, and lists the final outcomes of the finished inventories. Table 2 and the appendix illustrate the difference between the two inventories in Toronto; the UFORE study and the Toronto Maintenance and Management System (TMMS).

Respondents in both North America and European cities mentioned operational planning and arboricultural work as reasons for conducting the inventory in addition to budget and strategic planning, traffic safety, recording and centralizing information, investigating alternative management structures, and monitoring changes to the urban forest. The inventory in Aarhus and Toronto's TMMS inventory were used for insect and disease control; Aarhus in particular wanted to assess the impact of Dutch elm disease. The Oslo tree inventory held the aim of centralizing the information that the operational division had regarding the urban forest. There had been a separation between the operational division and the parks and recreational department, implying that important information regarding the urban forest might get lost. Hence it was necessary to centralize the information. In Copenhagen, the inventory was meant to optimize the dialogue between different departments in the city and clarify any ownership issues regarding trees. The objective of the UFORE study in Toronto was to assess and communicate the values and services provided by the urban forest, and to improve the understanding of the entire urban forest composition, including parks and private lands.

None of the cities in Scandinavia mentioned the values and benefits gained from the urban forest as reasons for performing the inventory, while this objective was stressed in both Toronto

Table 1. Questionnaire for the urban foresters.

\begin{tabular}{ll}
\hline Questions regarding the inventory & Questions regarding what happened after the inventory \\
\hline When was the last inventory performed? & What happened after the inventory had been completed? \\
What percentage of trees were inventoried? & Was a management plan developed as a result of the inventory? \\
Who performed the inventory? & How has the public been involved in or after the inventory was \\
Which trees were inventoried? & How is the inventory being updated? \\
Was aerial information used as well & \\
as ground information? & \\
What was the purpose of the inventory? & \\
Who initiated the inventory? & \\
$\begin{array}{l}\text { Did the city develop the inventory themselves, } \\
\text { or was the inventory developed by }\end{array}$ & \\
another city/ consulting company?
\end{tabular}


and New York City. In New York City, the department of parks and recreation wanted to highlight the important relationship between the urban forest and the quality of urban life, whilst Toronto's UFORE study focused on communicating the values and services provided by the city's urban forest. In Boston, the "growing awareness of importance of urban forestry management and [the] recognition that little was known about the extent and condition of [the] urban forest" (Urban Ecology Institute 2008), together with a need to back up statements regarding the urban forest canopy, was the major reason for conducting the inventory.

Only New York City and Boston used volunteers in carrying out their inventories. In Boston, the inventory was performed by contractors and 300 volunteers; in New York City, it was performed by city staff, contractors, and approximately 1100 volunteers.

All but two of the inventories focused solely on street trees and park trees that border closely to roads. Oslo inventoried both street and park trees, although their inventory only covered $10 \%-20 \%$ of the city-owned trees. The UFORE study in Toronto inventoried street, park, and private trees.

Both New York City and Toronto had been updating their street tree inventories on a regular basis. Their inventories are incorporated into their work order system, so that when arboricultural work is performed, any change in a tree's status is updated and recorded in the inventory, along with the work that has just been performed.

The pilot study also revealed that after the inventories had been completed, none of the cities had taken their inventory to the next level and used it to produce a strategic management plan.

\section{DISCUSSION}

The main reasons for conducting inventories were found to be similar between major cities in North America and Scandinavia, in terms of centralizing and recording information, and strategic planning. However, the differences between the two continents were related to the overall reasons for performing the inventories. In North America, there was a focus on the economic, environmental, and social benefits gained from the urban forest. In the Scandinavian cities, none of these benefits were mentioned or recognized in the inventory process.

Another important difference between the cities studied relates to the roles of professionals and volunteers when performing tree inventories. The benefits of using volunteers include enhanced social cohesion, building an active citizenry, and strengthening democracy. Studies have shown that volunteers are more likely to be more engaged in the governance of their community (Rochester et al. 2010). In addition, the use of volunteers can create a network with a strong political voice, which can in turn be used in favor of the urban forest (Bloniarz and Ryan 1996). The Department of Parks and Recreation in New York City considered the benefits gained from using volunteers important, even though they realized that the inventory might have been more accurate if only professionals had been involved. To save time, the New York City volunteers had been trained to enter their own data, as also mentioned by Abd-Elrahman et al. (2010). However, the municipality of Oslo regarded the quality of the inventory as their highest priority, and the arborists who performed the inventory needed at least three years' experience of arboricultural work, including experience with condition rating. The problem of validity in volunteer-recorded results can be dealt with by using verification field crews and by cross-checking parts of the data (Abd-Elrahman et al. 2010). In addition, Bloniarz and Ryan (1996) showed that the use of volunteers provides data with validity comparable to that of professionals (Bloniarz and Ryan 1996).

One of the obstacles in performing an inventory is the high percentage of trees located on private land (hence the reason most inventories focus on public street trees). This was also apparent in the pilot study. None of the cities in question have management responsibilities over private trees, so it can be argued that it makes economic sense for them to not be included.

Updating inventories seems to be a common challenge, even though a continuous update is necessary to achieve the goals and aims commonly expressed as the reasons for performing an in-

Table 2. Information collected in each tree inventory, by whom, and the outcomes.

\begin{tabular}{|c|c|c|c|c|c|c|c|}
\hline & & Toronto & Boston & New York City & Copenhagen & Aarhus & Oslo \\
\hline \multirow[t]{3}{*}{ Who performed inventory? } & City & $\mathrm{XU}$ & & $\mathrm{X}$ & $\mathrm{X}$ & $\mathrm{X}$ & \\
\hline & Contractor & & $\mathrm{X}$ & $\mathrm{X}$ & & & $\mathrm{X}$ \\
\hline & Volunteer & & $\mathrm{X}$ & $\mathrm{X}$ & & & \\
\hline \multirow[t]{2}{*}{ Ground/Aerial } & Ground & X U & $\mathrm{X}$ & $\mathrm{X}$ & $\mathrm{X}$ & $\mathrm{X}$ & $\mathrm{X}$ \\
\hline & Aerial & X U & $\mathrm{X}$ & & $\mathrm{X}$ & $\mathrm{X}^{\mathrm{z}}$ & \\
\hline \multirow[t]{2}{*}{ Which trees were inventoried? } & Park & $\mathrm{X}^{\mathrm{y}} \mathrm{U}$ & & $\mathrm{X}^{\mathrm{y}}$ & $\mathrm{X}^{\mathrm{y}}$ & $\mathrm{X}^{\mathrm{y}}$ & $\mathrm{X}$ \\
\hline & Private & $\mathrm{U}$ & & & & & \\
\hline \multirow[t]{2}{*}{ Development of inventory } & City & $\mathrm{X}$ & & $\mathrm{X}$ & $\mathrm{X}$ & $\mathrm{X}$ & \\
\hline & Contractor & $\mathrm{U}$ & $\mathrm{X}$ & & & & $\mathrm{X}$ \\
\hline \multirow[t]{2}{*}{ Product of inventory } & Management plan & & & & & & \\
\hline & Work order system & $\mathrm{X}$ & & $\mathrm{X}$ & & & \\
\hline $\begin{array}{l}\text { Total number of parameters } \\
\text { in inventory }\end{array}$ & & $\begin{array}{l}\text { X-15, U-10 } \\
\text { (20 total) }\end{array}$ & 20 & 14 & 16 & 17 & 8 \\
\hline
\end{tabular}

${ }^{z}$ Aerial only used to identify trees when residents have a request. Not used in the inventory.

${ }^{y}$ Some park trees were included if they were bordering a road.

w Only the number of trees is being updated. Arboricultural work and conditions are not being updated.

Note: $\mathrm{U}=\mathrm{UFORE}$ data collected 
ventory, and also for the inventories to remain valid and useful over time. Due to their continuous updating, New York City and Toronto have the most current information available about the health and condition of their urban forest, and therefore have the most comprehensive and useful inventories. Correct updating relies on the city crew being trained to record data that accurately reflects the status of the trees (Miller 1997). There is a lack of knowledge on this updating process, as well as on whether the inventories are being incorporated into the work order system, and if they are being used as a base for strategic management.

The New York City and Boston inventories spurred projects related to the urban forest and have involved their local communities. There seems to be a large difference in engagement with the urban forest in North America compared to Scandinavia. No volunteers were used in Scandinavia when carrying out the inventory, and no further communityengaging projects were started as a result of the inventory.

\section{FURTHER RESEARCH}

This pilot study provides a possible set-up for studying city urban forest inventories, enabling more in-depth analysis and comparison between cities. The study could form the basis for a larger study that may include more cities, which would make comparison between the two regions easier. The study has also made it clear that more research is needed on the status of urban forest inventories, the way they are set up and carried out, and on how they are used in planning and management. The accuracy and the validity of different types of inventories are also issues to be considered in future research, as well as the updating of inventories. It would also be useful to further include a policy analysis and perform a closer study of the societal aspects of urban forestry. Further studies in this direction could make it easier to understand the different reasons for performing inventories, such as the focus on the environmental and social aspects of the urban forest in North America, compared to the lack of focus on this aspect in Scandinavian cities. More research is also required on the inclusion of both private and public trees in inventories, something which is crucial in order to have a base for assessing the environmental benefits of urban trees.

Further research and comparative studies could give a more in depth reasons as to the different approaches to inventories and how they are performed. This in turn could provide more insight into the benefits gained from the respective different ways of performing inventories, and hence provide new ideas and additions to inventory updates in other cities, or inspire and help other cities start and complete an inventory.

Research into these issues could provide a base for developing national and international standards and recommendations for performing urban forest inventories. International standards could make it easier in the future to compare the urban forest in the different cities, and for other cities to gain inspiration for performing an inventory and the more strategic use of inventory data. The International Society of Arboriculture, the USDA Forest Service, and the International Union of Forestry Research Organizations have been working on developing international standards for urban forestry data collection. This standardization of data collection will hopefully facilitate cooperation between communities on a national and international level in terms of sharing data and analyzing their results, and will help promote urban forest management globally. Standardization will help with the development of urban forest tools and reduce the costs of data collection and analysis. Cities using this standardization will have access to low-cost tools to quantify and measure their urban forest, in addition to comparing their results with other cities in the world (Nowak 2008; Nowak 2009).

\section{CONCLUSION}

This explorative study of large cities points at the general differences between North America and Europe in terms of reasons for conducting inventories, how they were performed, and the way in which they are used. The pilot study also demonstrates that none of the investigated cities have a complete and regularly updated inventory of their urban forest, nor a management plan for improving their urban forest based on their tree inventory. The study provides a base for more comprehensive and comparative research on urban forest inventories, identifying good practices and providing a base for standardization, and a more strategic use of inventory data.

\section{LITERATURE CITED}

Abd-Elrahman, A.H., M.E. Thornhill, M.G. Andreu, F. Escobedo. 2010. A community-based urban forestry inventory using online mapping services and consumer-grade digital images. International Journal of Applied Earth Observations and Geoinformation 12:249-260.

Ames, R.G. 1980. The sociology of urban tree planting. Journal of Arboriculture 6(5):120-123.

Banks, J.C., C.L. Brack, and R.N. James. 1999. Modelling changes in dimensions, health status, and arboricultural implications for urban trees. Urban Ecosystems 3:35-43.

Bloniarz, D.V., and D.H. Ryan. 1996. The use of volunteer initiatives in conducting urban forest resource inventories. Journal of Arboriculture 22(2):75-82.

Brack, C.L. 2006. Updating urban forest inventories: An example of the DISMUT model. Urban Forestry and Urban Greening 5:189-194.

City of Toronto. Toronto Backgrounder: Release of 2006 Census results, age and sex population counts. Accessed 12/20/2010. $<$ http://www.toronto.ca/demographics/pdf/2006_age_and_sex_ backgrounder_with_maps.pdf>

Cumming, A.B., D.B. Twardus, and D.J. Nowak. 2008. Urban forest health monitoring: Large-scale assessment in the United States. Arboriculture \& Urban Forestry 34(6):341-346.

Danmarks Statestik. 2010. Table 12: Folketal i de enkelte kommuner og regioner. Accessed 08/26/2010. <www.dst.dk/aarbogstabel/12>

Duntemann, M., and S. Gasperini. 2006, The Tree Inventory as a Proactive Management Tool, Presented at the 9th European Forum on Urban Forestry, Vallombrosa, Italy May 22-26.

Gartner, J.T., T. Treiman, and T. Frevert. 2002. Missouri urban forest: A ten-year comparison. Journal of Arboriculture 28(2):76-83.

International Society of Arboriculture. Verify an ISA certification/Find a Tree Care Service. Accessed 03/15/2011. <www.isa-arbor.com/faca/ findArborist.aspx $>$

Jim, C.Y. 2008. Multipurpose census methodology to assess urban forest structure in Hong Kong. Arboriculture \& Urban Forestry 34(6):366-378.

Konijnendijk, C.C., R.M. Ricard, A. Kenney, and T.B. Randrup. 2006. Defining urban forestry - A comparative perspective of North America and Europe. Urban Forestry and Urban Greening 4:93-103. 
McPherson, E.G., D.J. Nowak, G. Heisler, S. Grimmond, C. Souch, R. Grant, and R. Rowntree. 1997. Quantifying urban forest structure, function, and value: The Chicago Urban Forest Climate Project. Urban Ecosystems 1:49-61.

Miller, R.W. 1997. Urban forestry: Planning and managing urban greenspaces. 2nd Edition. Prentice Hall, Upper Saddle River, New Jersey, U.S. 07458. pp. 27-117.

Millward, A.A., and S. Sabir. 2011. Benefits of a forested urban park: What is the value of Allan Gardens to the city of Toronto, Canada? Landscape and Urban Planning 100:177-188.

Nowak, D.J. 2008. Assessing urban forest structure: Summary and conclusion. Arboriculture \& Urban Forestry 34(6):391-392.

Nowak, D.J. 2009. International Urban Forest Data Standards Committee. ISA and IUFRO. Accessed 08/26/2010. <http://unri.org/iufro/ wp-content/uploads/2009/05/standardization-team.pdf>

Petersen, K.H. 2003. Træregistrering som forvaltningsværktøj. En undersøgelse af elektroniske gadetræsregistreringer i 5 europæiske storbyer, med udgangspunkt i Københavns Kommune. 36-point speciale ved Institut for Økonomi, Skov og Landskap, KVL.

Rochester, C., A. Ellis Paine, and S. Howlett. 2010. Volunteering and Society in the 21st century. Palgrave Macmillan, Hampshire, UK.

Sejr, O., and B. Manning. 2011. Det er for få certificerede træ-plejere. Grønt Miljø 2:62-64.

Smiley, T.E., and A.F. Baker. 1988. Options in street tree inventories. Journal of Arboriculture 14(2):36-42.

Soares, A.L., F.C. Rego, E.G. McPherson, J.R. Simpson, P.J. Peper, and Q. Xiao. 2011. Benefits and costs of street trees in Lisbon, Portugal. Urban Forestry and Urban Greening <doi:10.1016/j.ufug.2010.12.001>

Statistics Norway. Folkemengde 1.januar 2009 og endringer i 4. kvartal 2008. Akershus og Oslo. Accessed 08/25/2010. <www.ssb.no/emner/02/02/folkendrkv/2008k $4 / \mathrm{kvart} 02 . \mathrm{html}>$

Stewart, G.H. 2009. Urban biotopes of Aoteara New Zealand (URBANz) II: Floristics, biodiversity and conservation values of urban residential and public woodlands, Christchurch. Urban Forestry and Urban Greening 8:149-162.
Sudha, P., and N.H. Ravindranath. 2000. A study of Bangalore urban forest. Landscape and Urban Planning 47:47-63.

U.S. Census Bureau. State and county quick facts: Boston (city), Massachusetts. Accessed 08/25/2010. <http://quickfacts.census.gov/qfd/ states/25/2507000.html>

U.S. Census Bureau. State and county quick facts: New York. Accessed 08/25/2010. <http://quickfacts.census.gov/qfd/states/36000.html>

Urban Ecology Institute. 2008. State of the Urban Forest: A summary of the extent and condition of Boston's urban forest.

Vollbrecht, K. 1988. Tree care in Scandinavia. Journal of Arboriculture 14(1):3-6.

Ward, K.T., and G.R. Johnson. 2007. Geospatial methods provide timely and comprehensive urban forest information. Urban Forestry and Urban Greening 6:15-22.

Welch, J.M. 1994. Street and park trees of Boston: A comparison of urban forest structure. Landscape and Urban Planning 29:131-143.

Julie Kjeldsen-Kragh Keller (corresponding author)

Master of Forest Conservation

Director, Urban Nature Consultants

Ved Amagerport 12 st.th

2300 Copenhagen $S$

Denmark

keller@urbannatureconsultants.com

Cecil C. Konijnendijk

Professor, Green Space Management

Danish Centre for Forest, Landscape and Planning

Faculty of Life Sciences

University of Copenhagen

Rolighedsvej 23

1958 Frederiksberg $C$

Denmark

cck@life.ku.dk 
Résumé. Une gestion efficace de la forêt urbaine implique pour les municipalités d'avoir un inventaire des arbres. L'approche en foresterie urbaine est quelque peu différente en Europe et Amérique du Nord, à la fois en terme de compétence et de culture. Cet article discute des similarités et des différences dans les pratiques d'inventaire des arbres en se basant sur une étude pilote de trois grandes villes d'Amérique du Nord (Toronto dans la province de l'Ontario au Canada, Boston dans l'état du Massachusetts et New York dans l'état de New York aux États-Unis) ainsi que trois grandes villes d'Europe (Oslo en Norvège, Aarhus et Copenhague au Danemark). L'étude pilote consistait à mener des interviews semi-structurées auprès de chacune des villes et d'analyser leur inventaire d'arbres en terme de niveau de détail, de comment ils avaient été réalisés et comment ils étaient utilisés. Chacune des villes, à l'exception de Oslo, avait inventorié chacun de ses arbres de rues. Des volontaires ont été utilisés seulement à Boston et à New York. Aucune des villes n'avait développé de plan de gestion en se basant sur son inventaire d'arbres. L'inventaire avait été complètement incorporé dans le système d'organisation du travail seulement dans les villes de New York et de Toronto. Cette étude exploratoire démontre que plus de recherche s'avère nécessaire afin de déterminer ce qu'il advient subséquemment aux inventaires d'arbres dans les villes après qu'ils aient été réalisés. De plus, plus de travail est nécessaire pour déterminer si les inventaires sont utilisés à leur plein avantage en terme de production de plans de gestion. Certains thèmes clés pour des recherches futures sont décrits. Le format de cette étude pilote pourrait servir de cadre pour une étude plus approfondie.

Zusammenfassung. Eine effektive Verwaltung von urbanen Wäldern ruft bei den Verantwortlichen nach einer Inventur ihres Baumbestandes. Der Ansatz von urbaner Forstwirtschaft ist in Nordamerika und Europa sehr verschieden, sowohl in Bezug auf den Hintergrund als auch die Kultur. Dieser Beitrag diskutiert die Ähnlichkeiten und Unterschiede bei den Bauminventur, basierend auf einer Pilotstudie in drei größeren Städten in Nordamerika (Toronto, Ontario, Kanada; Boston, Massachusetts und New York City, New York, U.S.) und drei größeren Städten in Nordeuropa (Oslo, Norwegen; Aarhus und Kopenhagen, Dänemark). Die Pilotstudie bestand aus semi-strukturierten Experten-Interviews in jeder Stadt und einer Analyse der bestehenden Bauminventuren in Bezug auf ihre Details, wie sie angefertigt werden und wie sie verwendet werden.
Jeder der Städte mit der Ausnahme von Oslo hatte alle Straßenbäume in einem Kataster erfasst. Freiwillige wurden nur in Boston und New York eingesetzt. Keine der Städte hatte einen Managementplan aufgrund des erstellten Katasters entwickelt. Das Kataster wurde nur in Toronto und New York vollständig in das Management integriert. Diese erhebende Studie zeigte, dass mehr Forschung erforderlich ist, um zu untersuchen, was im Anschluss an die Erstellung des Baumkatasters in den Städten damit passiert. Mehr noch, um zu identifizieren, ob die Baumkataster zum vollen Vorteil als Grundlage zur Entwicklung von Managementplänen ausgenutzt werden, ist mehr Forschung erforderlich. Einige Schlüsselthemen für künftige Forschungen werden beschrieben. Der Aufbau dieser Pilotstudie könnte als Format für grundlegende Forschung dienen.

Resumen. El manejo efectivo del bosque urbano llama a las municipalidades a tener un inventario de árboles de su recurso urbano. La aproximación a la dasonomía urbana es bastante diferente en Europa y Norte América, ambos en términos de origen y cultura. Esta contribución discute similitudes y diferencias en las prácticas de inventario, basadas en un estudio piloto de tres ciudades principales en Norte América (Toronto, Ontario, Canadá; y Boston, Massachusetts y New York City, New York, U.S.) y tres ciudades principales en el Norte de Europa (Oslo, Norway; y Aarhus y Copenhagen, Denmark). El estudio piloto consistió de entrevistas semi-estructuradas a expertos en cada ciudad, y un análisis de sus inventarios de árboles en términos de su nivel de detalle, cómo fueron ellos entendidos y cómo fueron usados. Cada una de las ciudades, con excepción de Oslo, inventarió a todos sus árboles de las calles. Se emplearon voluntarios solamente en Boston y New York City. Ninguna de las ciudades había desarrollado un plan de manejo basado en su inventario de árboles. El inventario solo había sido incorporado en el sistema de orden de trabajo en New York City y Toronto. Este estudio explicativo muestra que se requiere más investigación para conocer qué sucede con los inventarios de árboles en municipalidades después de que se han realizado. Además, se requiere más trabajo para identificar si los inventarios están siendo utilizados en todo su potencial en términos de producción de planes de manejo. Se describen algunos temas clave para investigación futura. El montaje del estudio piloto podría servir como un formato para una investigación más comprensiva. 
APPENDIX. Information for the six cities studied regarding the population, year inventory was performed, completeness of inventory, and reasons for undertaking the inventory.

\begin{tabular}{|c|c|c|c|c|}
\hline & Population & $\begin{array}{l}\text { Year of } \\
\text { inventory }\end{array}$ & $\begin{array}{l}\text { Completeness of } \\
\text { inventory }\end{array}$ & Reasons for inventory \\
\hline Aarhus & $\begin{array}{l}306,650 \\
\text { (Danmarks } \\
\text { Statistik 2010) }\end{array}$ & $\begin{array}{l}\text { 2004, } \\
\text { update } 2009\end{array}$ & $\begin{array}{l}\text { 2004: all street trees } \\
\text { in four districts. } \\
\text { 2009: only street } \\
\text { trees "inner city." }\end{array}$ & $\begin{array}{l}\text { - Data on the size of the urban forest was required for budgetary } \\
\text { reason } \\
\text { - To assess the impact and seriousness of Dutch elm disease } \\
\text { (Ophiostoma novo-ulmi) } \\
\text { - Traffic safety and identification of hazardous trees }\end{array}$ \\
\hline Copenhagen & $\begin{array}{l}528,208 \\
\text { (Danmarks } \\
\text { Statistik 2010) }\end{array}$ & $2000 / 2001$ & $\begin{array}{l}100 \% \text { street trees of } \\
\text { municipal owned } \\
\text { trees }\end{array}$ & $\begin{array}{l}\text { - Required for the budget } \\
\text { - To optimize arboricultural work and watering } \\
\text { - To optimize dialogue between departments and to clear up } \\
\text { tree ownership issues } \\
\text { - To be used as a tool in replanting decisions and to aid in } \\
\text { choosing species }\end{array}$ \\
\hline Oslo & $\begin{array}{l}575,574 \\
(\text { Statistics } \\
\text { Norway 2010) }\end{array}$ & $\begin{array}{l}\text { 2006, } \\
\text { update } 2009\end{array}$ & $\begin{array}{l}\text { Approx. } 10 \%-20 \% \\
\text { of street trees }\end{array}$ & $\begin{array}{l}\text { - To record and centralize information, required due to a } \\
\text { separation between the operational division and the parks } \\
\text { and recreational department }\end{array}$ \\
\hline New York & $\begin{array}{l}8,214,426 \\
\text { (U.S. Census } \\
\text { Bureau 2010) }\end{array}$ & 2006 & $100 \%$ street trees & $\begin{array}{l}\text { - To gain information on structure, value, function and } \\
\text { management needs of the urban forest } \\
\text { - To assist in funding decisions and to evaluate program } \\
\text { cost-efficiency } \\
\text { - To investigate alternative management structures } \\
\text { - To highlight the important relationship between the urban } \\
\text { forest and the quality of local life }\end{array}$ \\
\hline Boston & $\begin{array}{l}590,763 \\
\text { (U.S. Census } \\
\text { Bureau 2010) }\end{array}$ & 2006 & $100 \%$ street trees & $\begin{array}{l}\text { - A "growing awareness of importance of urban forestry } \\
\text { management and recognition that little was known about } \\
\text { extent and condition of urban forest" (Urban Ecology } \\
\text { Institute 2008) } \\
\text { - To back up a statement about canopy cover in Boston }\end{array}$ \\
\hline Toronto & $\begin{array}{l}2,503,281 \\
\text { (City of } \\
\text { Toronto 2006) }\end{array}$ & $\begin{array}{l}\text { 2000, Toronto } \\
\text { Maintenance } \\
\text { and Management } \\
\text { System (TMMS) } \\
\text { 2008, Urban } \\
\text { Forest Effects } \\
\text { Model } \\
\text { (UFORE) }\end{array}$ & $\begin{array}{l}\text { Sample-based } \\
\text { inventory through } \\
\text { UFORE }\end{array}$ & $\begin{array}{l}\text { - Required for operational and strategic planning, including; risk } \\
\text { management, insect and disease control, tracking species } \\
\text { composition, planning for planting, tree maintenance, and } \\
\text { removal } \\
\text { - To monitor change in the urban forest } \\
\text { - To help quantify and communicate the values and services } \\
\text { provided by the urban forest. } \\
\text { - Toimprove the understanding of the entire urbanforestcom- } \\
\text { position and function, including private lands and parks. } \\
\text { - To provide valuable information for strategic planning } \\
\text { and a framework for monitoring change. }\end{array}$ \\
\hline
\end{tabular}

